\title{
Combinatorial therapeutic plan for COVID-19 treatment armed up with antiviral, antiparasitic, cell- entry inhibitor, and immune-boosters
}

Nabanita Roy Chattopadhyay

Visva-Bharati, Santiniketan https://orcid.org/0000-0002-3809-6795

Koustav Chatterjee

Visva-Bharati, Santiniketan

Antara Banerjee

Bangabasi College, Kolkata

Tathagata Choudhuri ( $\nabla$ tathagata.choudhuri@visva-bharati.ac.in )

Visva-Bharati, Santiniketan https://orcid.org/0000-0003-4022-0318

\section{Research Article}

Keywords: COVID-19, SARS-CoV-2, Pandemic, FDA-approved drugs, Supplements, Immuneboosters

Posted Date: August 6th, 2020

DOI: https://doi.org/10.21203/rs.3.rs-53881/v1

License: (a) (i) This work is licensed under a Creative Commons Attribution 4.0 International License. Read Full License 


\section{Abstract}

SARS-CoV-2, or novel coronavirus, is causing the fatal and contagious coronavirus disease-2019 (COVID19) affecting thousands of people every single day. Researchers are continuously searching for any possible cure and/or vaccine, but no conclusive report is available till date. Like many others, we realize that a rapid, immediate, and elaborate strategy must be adopted to protect mankind. To avoid the timeloss due to clinical trials, we have tested some FDA-approved drugs to combat COVID-19. We accessed information from public databases and publications, and studied the mechanism of infection of SARSCoV-2 and the interactions of various drugs with SARS-CoV-2 proteins in silico. We found a few antivirals and antiparasitic drugs to interact with important SARS-CoV-2 proteins. Particularly Galidesivir, Remdesivir, and Pirodavir are the chosen antiviral drugs; and Proguanil, Mefloquine, and Artesunate are the chosen antiparasitic drugs. In addition, inhibitors to prevent host-cell entry and a few supportive immuneboosters can be used in different combinations. Our study proposes a four-way attack to this fatal virus for the possible management of COVID-19 armed up with an antiviral, an antiparasitic drug, a cell-entry inhibitor, and a few supportive immune-boosters, which can be used in different combinations in different groups of people.

\section{Introduction}

Severe acute respiratory syndrome coronavirus 2 (SARS-CoV-2), or novel coronavirus, is the causative agent of the fatal and contagious coronavirus disease-2019 (COVID-19), which has first been reported in December, 2019 in the capital of Hubei province in China, named Wuhan [1,2]. Since then, it has continued to spread throughout the world irrespective of the socio-economic status, ethno-genetic diversity, and topographical differences $[3,4]$. According to World Health Organization (WHO), the disease is a Public Health Emergency of International Concern (PHEIC) and symptoms include dry cough, fever, breathing trouble, and other symptoms of common flu; however, death due to severe pneumonia and multi-organ failure is noted in immune-compromised people [3,4]. The situation is frightening as the basic reproduction number $\left(R_{0}\right)$ of the virus is 1.4 to 3.9 in different countries, i.e. one infected person can infect 1.4 to 3.9 new people [3-5]. Considering the huge population of human beings and the universal susceptibility towards this virus, this can pose a serious threat to mankind. Unfortunately, no cure or vaccine is known till date. And finally, the most alarming one is, the mechanism of infection of this virus is quite complex and it might be present in other mammals also [3,5-10]. The infection usually spreads during close contact with infected persons through respiratory droplets produced by coughing and sneezing $[3,11]$. Diagnosis can be confirmed by reverse transcription polymerase chain reaction (rRT-PCR) taking a nasopharyngeal swab $[4,12]$. Incubation period of the virus may be as long as two weeks or even more; therefore social distancing, use of masks, hand washing, personal hygiene, and healthy lifestyle are the only methods suggested to prevent the infection [3,4].

SARS-CoV-2 is a positive-sense single-stranded RNA virus (+SSRNA virus) which uses its RNA as its genetic material as well as mRNA for the viral protein production (Figure 1a,b,c) [3,11,12]. The individuum belongs to the realm Riboviria, order Nidovirales, family Coronaviridae, genus 
Betacoronavirus, subgenus Sarbecovirus, and species Severe acute respiratory syndrome related coronavirus [13]. Though this virus shows significant homology with the bat-coronaviruses and its homologue found in pangolins, the severity and mode of infection of SARS-CoV-2 is attributed to the presence of a cleavage site for furin endoproteases in the junction of the S1 and S2 domains of the spike glycoprotein [7-9,12,14]. The S1 part attaches the virion to host-ACE2 (angiotensin-converting enzyme 2), a cell-surface receptor found in various tissue types including the alveolar epithelial cells, and is internalized inside the endosome. This primes the $S 2$ by cleaving the $S 1 / S 2$ junction by the cellular serine protease, transmembrane protease serine 2 (TMPRSS2), which actually is a furin endoprotease, and unmasks it for the fusion of the viral and cellular endosome membranes. This fusion facilitates the viral genome to enter into the cytoplasm of the host cell and establish infection [9,13-16].

Immediately after entering, the viral RNA uses the host-cell's protein synthesis machinery for producing its own proteins. The details of the nucleotide sequences, their respective peptide sequences, structures, and the annotated functions are available in public database

(https://swissmodel.expasy.org/repository/species/2697049) [4,11,13]. Two-thirds of the genome, called the ORF1ab is responsible for producing the ORF1ab replicase polyprotein; this actually produces a set of 16 mature viral proteins (each called a non-structural protein or nsp) needed for different aspects of establishment of infection [3,4,13-16]. The remaining parts encode the spike glycoprotein (S), small envelope protein (E), matrix protein (M), nucleocapsid protein (NC), and some accessory proteins to evade the host immune system.

nsp1, the first protein synthesized just after the 5'UTR of the viral mRNA, binds the host 40 S ribosomal subunit and stops host protein production by cleaving host-mRNAs near their 5'UTRs. Viral mRNAs are protected from such cleavage by a $5^{\prime}$-leader sequence. nsp 15 cleaves the long viral sense-RNA in mature fragments, each with a 5'cap-like structure made of a 2'-3'-cyclic phosphate, which structure protects the viral RNAs from host-mediated destruction. nsp10 stimulates two other mature viral proteins - nsp14 and nsp16. The N7-guanine methyltransferase activity of nsp14 adds the N7-methylguanosine cap to the viral mRNAs and recruits nsp16, which then adds a methyl group to the 2'-0-ribose of that N7-

methylguanosine. These form a compact cap on each viral mRNA and prepare that for protein production using the host-cell machinery. All these, and some other proteins, help the RNA-dependent RNApolymerase (RdRp), or $n s p 12$, to efficiently replicate and transcribe the viral genome and to generate new infective virions (Figure 1d) $[3,4,8,9,13]$.

SARS-CoV-2 do not lyse the host cell; instead, they 'bud'-off from the cell and infect nearby cells in the same way. As most of the human epithelial cells express ACE2, particularly the alveolar cells and those in the intestine, those infectious virions eventually spread throughout the body and may pose the host towards a critical condition [16]. But as no specific and confirmed drug or vaccination is available till date, immune-compromised people, for example persons having other diseases, may sometimes face severe complications due to COVID-19 and may even die due to acute respiratory distress syndrome (ARDS) [3-5,9,12,16-18]. The complex signalling required for activating innate and adaptive immunity needs a lot of proteins to be expressed by the host. But in COVID-19, the initial stages of pathogenesis 
may suppress the immune responses of the host by suppressing the protein-production, as stated earlier $[3,14,16,17]$.

Designing a successful and universal treatment regime for COVID-19 patients becomes critical due to these above discussed mechanism of infection of the virus and the respective host responses. Therefore, a combinatorial approach is needed to attack the disease from three sides: a drug to kill or stop the virus; a chemical blocker for any step of the establishment of the infection; and last but not the least, an immune-booster to support the actions of the former two. We have reviewed detailed information about COVID-19 and SARS-CoV-2 as published in literature and public databases, and analysed a few molecules for this above said treatment proposal.

\section{Materials And Methods}

\section{Collection of data and downloading the structures}

Whole genome sequence of SARS-CoV-2 has been collected from National Center for Biotechnology Information (NCBI) (https://www.ncbi.nlm.nih.gov/nuccore/NC_045512). The '.pdb' files for the structures of viral proteins are downloaded from the Protein Data Bank (pdb) site (https://www.rcsb.org/). The characteristic of each of the proteins has been collected form NCBI, Swiss Model Repository, and pdb site.

\section{Screening of protein-ligand docking}

Interactions of the viral proteins with the drug candidates [https://drugbank.ca] have been checked by the virtual screening tool PyRx and protein-ligand dockings have been checked by AutoDock Vina. These softwares have been downloaded as a package from http://autodock.scripps.edu/. The charts shown in Figures 2 and 3 have been prepared with Microsft Excel.

\section{Analyses of protein-ligand docking interactions}

After successful docking of some drug candidates, the interactions of the regions of viral proteins with the regions of the drug candidates have been checked by the PyMOL software downloaded from https://pymol.org/. Specific interactions with amino acids of viral proteins and atoms of the drugs have been analysed by the Discovery Studio Visualizer downloaded from the link https://www.3dsbiovia.com/products/collaborative-science/biovia-discovery-studio/visualizationdownload.php.

\section{Results And Discussion}

Based on the experiences on SARSCoV, MERS-CoV, Ebola virus, malaria, and influenza, a few antiviral drugs are thought to effectively stop the SARS-CoV-2 spread [17,18]. Oseltamivir, Peramivir, Zanamivir, Ganciclovir, Acyclovir, and Methylprednisolone are already reported to be almost ineffective against 
SARS-CoV-2. Some other antiviral drugs like Umifenovir, Galidesivir, Ribavirin, Triazavirin, Ritonavir, Nitazoxanide, Favipiravir, Lopinavir, Ritonavir, Nafamostat, Darunavir and Remdesivir, and an antimalarial drug Chloroquine, have been used separately or in combination to treat COVID-19 patients. Though some effects and even recovery is reported for each of those treatment plans, none are found promising except a combination of Remdesivir and Chloroquine [17-23]. Viral infections can suppress host immunity, and previous reports show that application of immune-boosters like interferons along with an antiviral drug can help survival and prognosis $[20,21,24]$. Therefore scientists are working on combinatorial approaches using different drugs like Remdisivir and/or Chloroquine along with immune-boosters. Recently, a blocker for ACE2 or TMPRSS2 is being tried to prevent the viral entry in to the host cell. Interestingly, WHO has announced a combinatorial approach using Remdisivir, Chloroquine, a blocker as said above, and an immune-booster as said above $[3,14,17,18]$. We have screened a lot of candidate molecules by checking the binding properties of those with different essential viral proteins separately. The possible efficacy of any candidate drug helped us suggest a possible combinatorial treatment plan to be implemented.

\section{Remdesivir, Galidesivir, and Pirodavir are the choice of antiviral drugs}

After initial screening, we have finalized a set of six antiviral drug candidates for detailed study to propose the combinatorial therapy (Table 1). Receptor-ligand interactions are analysed taking the drugs and the important viral proteins individually. We have chosen the drugs which show at least one interaction with at least one viral protein with at least $-0.7 \mathrm{kcal} / \mathrm{mol}$ of binding energy (Table 1 , Supplementary table 1).

Remdesivir has already proved its efficacy against SARS-CoV-2. In our screening methods, we also have found that this drug can interact with a variety of viral proteins. Two other drugs, Galidesivir and Pirodavir, also seem promising as they can target more than one viral protein (Figure 2, Table 1, Supplementary table 1). Interestingly, none of these can interact effectively with the receptor-binding domain (RBD) of the SARS-CoV-2 spike glycoprotein; thereby they cannot prevent the entry of the virus into the host cell (Supplementary figures 1,2).

Some other drugs may serve as the promising candidates for using in combination with the antivirals

A Chloroquine derivative, Hydroxychloroquine, is being widely used as a promising treatment strategy for COVID-19 $[3,26,27]$. Though we have found Chloroquine to interact with some SARS-CoV-2 proteins (Figure 3a), it should be noted that Hydroxychloroquine can reduce both innate and adaptive immune responses significantly by suppressing Toll-like receptor signalling (TLR) pathways [28-30]. Therefore the use of Chloroquine molecule in must be monitored carefully, and we exclude this known molecule from our proposals.

We have searched for a few FDA- (the U.S. Food and Drug Administration) approved drugs and/or chemical which might prove them promising for the management of COVID-19 (Table 1) [31]. A recent report has already suggested Ivermectin for treating COVID-19, though the results are not confirmed in humans [26,32]. Looking on Chloroquine, we searched for other antimalarial drugs approved by FDA. We 
found that many of those show promising interactions with viral proteins (Figure 3b). Depending upon such possible interactions and reported side effects, we inferred that Proguanil, Artesunate, and Mefloquine may serve as candidates for the proposed combinatorial therapy. Artementher and Quinine may also be tested, but they show less favourable interactions (Figure 3b,c,d; Table 1, Supplementary figure 2).). Though Amodiaquine belongs to the WHO safe drug list, we have excluded that for its rare but serious side effects and interactions with certain genotype [32].

\section{Host cell entry of SARS-CoV-2 should be prevented}

None of the above chosen antiviral and antiparasitic drugs can interact with the Spike-RBD and RdRp. Therefore, they cannot prevent the viral entry as well as its replication. We have concentrated our next choice on any blocker which can prevent viral entry (Supplementary table 2) [14,33]. Angiotensinconverting enzyme (ACE) cleaves angiotensin I to generate angiotensin II and this binds angiotensin II type 1 receptor (AGTR1) which constricts blood vessels, thereby elevates blood pressure. On the other hand, ACE-2 inactivates angiotensin II and helps vasodilation. Inhibitors to AGTR1, like Losartan and Olmesartan, are reported to increase ACE2 and thus vasodilation [33,34]. Hypothetically, any blocker for ACE-2 might prevent host cell entry and thereby might prevent COVID-19 [35]. But the role of ACE-2 is essential for the survival of the host and it is already reported that reduced ACE-2 can lead to lung injury, arrhythmia and cardiac failure. In addition ACE-2 is found in a variety of organs and SARS-CoV-2 attacks those organs also resulting in low ACE-2 $[14,36,37]$. Therefore, the blockers against ACE or AGTR1 might be helpful as they can increase ACE-2 and might prevent pneumonia seen in COVID-19, as suggested by some $[38,39]$.

A recent report also suggests for an inhibitor for TMPRSS2, camostat mesylate, to inhibit the priming of spike glycoprotein and subsequent entry into the host cell [14]. Previously another inhibitor for TMPRSS2, Nafamostat, has been suggested for treating MERS-CoV and Ebola infections [39]. It is to be noted that SARS-CoV-2 is much similar to MERS-CoV and therefore, Nafamostat may also serve as a potential candidate for preventing SARS-CoV-2 entry into the host-cells.

\section{Vitamins $C, D, B 6$ and Zink can play as immuneboosters to fight COVID-19}

Host immunity plays the most important role for establishment and prognosis of any infection and supplements to boost immunity may be given to COVID-19 patients as suggested by some [40,41]. A healthy lifestyle and food helps immune system the most. But majority of the patients are not much immunocompetent due to reasons like unhealthy lifestyle, ageing, and poor socio-economic conditions. Therefore some approved supplements may be added to their treatment plan to fight COVID-19 successfully. Based on cited literature, we have chosen a few such candidates which might help treatment (Supplementary table 3) [40-43]. As discussed in other reports, along with these, interferon(s) may be given to the patients as a support to the drugs [24].

\section{$A, B, C$, and $D$ are the choices of treatment plans}


After detailed study, as discussed above, we have finalized a set of four treatment plans for the proper and effective management of COVID-19 (Figure 4; Table 2, Supplementary table 4). Possible adverse interaction(s) of each of these drugs has been searched from authentic public databases [44,45]. Any possible side effect(s) are also listed in the plans.

\section{Conclusion}

COVID-19 has made people reporting novel findings in various fields regularly. But the first and foremost task at present is to make people survive through this hell. As per the literature published till date, no one drug would serve the purpose of curing a significant number of patients. Rather, a combination of molecules, each targeting a specific step of infection, would be helpful for a full-proof treatment plan; and this has also been suggested by WHO recently [3]. Thus we propose a set of possible combinatorial treatment plans including an antiviral, an anitiparasitic drug, and an inhibitor for preventing host-cell entry. Additionally, we propose the use of some supplements and interferon(s) for boosting immunity and to support the effects of the drugs in immune-compromised patients. Of note, these supportive molecules and ACE- 2 induction by the above said inhibitors may also help prevent cytokine storm [36,37].

Though this study has been done in silico and needs wet-lab validations, most of these molecules are FDA-approved and has gone through the clinical trials. Therefore practising our proposal would help reduce the time for deciding about the treatment plans to be adopted in specific groups of people. Though we have checked drug interactions from public databases, it should be noted that the dose and dosage should be finalized very carefully by efficient and experienced healthcare professionals to prevent any unwanted adverse result(s). We hope that this study would pave a new thought to help the decision makers for the proper and widespread management of COVID-19.

\section{Declarations}

\section{Author contributions}

Investigation, Data Curation, Formal Analysis, and Writing - Original Draft Preparation: Nabanita Roy Chattopadhyay; Writing - Review \& Editing: Nabanita Roy Chattopadhyay, Koustav Chatterjee, Antara Banerjee, Tathagata Choudhuri; Resources: Nabanita Roy Chattopadhyay, Koustav Chatterjee, and Antara Banerjee; Funding Acquisition: Nabanita Roy Chattopadhyay and Tathagata Choudhuri; Conceptualization: Antara Banerjee and Tathagata Choudhuri; Project Administration and Supervision: Tathagata Choudhuri.

Acknowledgements: Post-doctoral fellowship to the first author has been provided by Indian Council of Medical research, Government of India (Proposal ID. 2019-4919). The corresponding author is a Fellow of the Indian Virological Society. The funders had no role in study design, data collection and analysis, decision to publish, or preparation of the manuscript. 


\section{References}

1. Chen L, Liu W, Zhang Q, Xu K, Ye G, Wu W, et al. RNA based mNGS approach identifies a novel human coronavirus from two individual pneumonia cases in 2019 Wuhan outbreak. Emerg Microbes Infect. 2020;9: 313-9.

2. Hui DS, I Azhar E, Madani TA, Ntoumi F, Kock R, Dar O, et al. The continuing 2019-nCoV epidemic threat of novel coronaviruses to global health-The latest 2019 novel coronavirus outbreak in Wuhan, China. Int J Infect Dis. 2020;91: 264-6.

3. World Health Organization. who.int. Accessed 18 June 2020.

4. Centers for Disease Control and Prevention. cdc.gov. Accessed 20 June 2020.

5. Branswell $\mathrm{H}$. Limited data on coronavirus may be skewing assumptions about severity. STAT. https://www.statnews.com/2020/01/30/limited-data-may-skew-assumptions-severity-coronavirusoutbreak/ Accessed 30 March 2020.

6. Wu JT, Leung K, Leung GM. Nowcasting and forecasting the potential domestic and international spread of the 2019-nCoV outbreak originating in Wuhan, China: a modelling study. Lancet. 2020;395: 689-97.

7. Zhang T, Wu Q, Zhang Z. Probable Pangolin Origin of SARS-CoV-2 Associated with the COVID-19 Outbreak. Curr Biol. 2020;30: 1346-51.

8. Zhang Y-Z, Holmes EC. A Genomic Perspective on the Origin and Emergence of SARS-CoV-2. Cell. 2020; pii: S0092-8674[20]30328-7. doi: 10.1016/j.cell.2020.03.035.

9. Lu R, Zhao X, Li J, Niu P, Yang B, Wu H, et al. Genomic characterisation and epidemiology of 2019 novel coronavirus: implications for virus origins and receptor binding. Lancet. 2020;395: 565-74.

10. Shang J, Ye G, Shi K, Wan Y, Luo C, Aihara H, et al. Structural basis of receptor recognition by SARSCoV-2. Nature. 2020; doi:10.1038/s41586-020-2179-y.

11. Jin YH, Cai L, Cheng ZS, Cheng H, Deng T, Fan YP, et al. A rapid advice guideline for the diagnosis and treatment of 2019 novel coronavirus [2019-nCoV] infected pneumonia. Med. Res. 2020;7: 4-26.

12. https://www.gisaid.org/ Accessed 30 May 2020.

13. Gorbalenya AE, Baker SC, Baric RS, de Groot RJ, Drosten C, Gulyaeva AA, et al. The species Severe acute respiratory syndrome-related coronavirus: classifying 2019-nCoV and naming it SARS-CoV-2. Nat Microbiol 2020, 5, 536-44.

14. Hoffmann M, Kleine-Weber H, Schroeder S, Krüger N, Herrler T, Erichsen S, et al. SARS-CoV-2 Cell Entry Depends on ACE2 and TMPRSS2 and Is Blocked by a Clinically Proven Protease Inhibitor. Cell. 2020; pii: S0092-8674[20]30229-4. doi: 10.1016/j.cell.2020.02.052.

15. Coutard B, Valle C, de Lamballerie X, Canard B, Seidah NG, Decroly E. The spike glycoprotein of the new coronavirus 2019-nCoV contains a furin-like cleavage site absent in CoV of the same clade. Antiviral Res. 2020;176: 104742. doi: 10.1016/j.antiviral.2020.104742.

16. Cui J, Li F, Shi ZL. Origin and evolution of pathogenic coronaviruses. Nat Rev Microbiol. 2019;17: 181-92. 
17. Guo YR, Cao QD, Hong ZS, Tan YY, Chen SD, Jin HJ, et al. The origin, transmission and clinical therapies on coronavirus disease 2019 [COVID-19] outbreak - an update on the status. Med. Res. 2020; doi: 10.1186/s40779-020-00240-0.

18. Wu C, Liu Y, Yang Y, Zhang P, Zhong W, Wang Y, et al. Analysis of therapeutic targets for SARS-CoV-2 and discovery of potential drugs by computational methods. Acta Pharmaceutica Sinica B. 2020. https://doi.org/10.1016/j.apsb.2020.02.008

19. Wang D, Hu B, Hu C, Zhu F, Liu X, Zhang J, et al. Clinical Characteristics of 138 Hospitalized Patients With 2019 Novel Coronavirus-Infected Pneumonia in Wuhan, China. Jama. 2020; doi: 10.1001/jama.2020.1585.

20. Li G, De Clercq E. Therapeutic options for the 2019 novel coronavirus [2019-nCoV]. Nature Reviews Drug Discovery 2020; 19: 149-50.

21. Wang $M$, Cao R, Zhang L, Yang $X$, Liu J, Xu M, et al. Remdesivir and chloroquine effectively inhibit the recently emerged novel coronavirus [2019-nCoV] in vitro. Cell res. 2020;30: 269-71.

22. Lim J, Jeon S, Shin HY, Kim MJ, Seong YM, Lee WJ, et al. Case of the Index Patient Who Caused Tertiary Transmission of COVID-19 Infection in Korea: the Application of Lopinavir/Ritonavir for the Treatment of COVID-19 Infected Pneumonia Monitored by Quantitative RT-PCR. Journal of Korean medical science. 2020; doi: 10.3346/jkms.2020.35.e79.

23. Holshue ML, DeBolt C, Lindquist S, Lofy KH, Wiesman J, Bruce H, et al. First Case of 2019 Novel Coronavirus in the United States. N Engl J Med. 2020; 382: 929-36.

24. Cinatl J, Morgenstern B, Bauer G, Chandra P, Rabenau H, Doerr HW. Treatment of SARS with human interferons. Lancet. 2003; 362: 293-4.

25. Information collected from internet. Available from: https://www.ebi.ac.uk/chembl/ Accessed 12 June 2020.

26. Caly L, Druce JD, Catton MG, Jans DA, Wagstaff KM. The FDA-approved Drug Ivermectin inhibits the replication of SARS-CoV-2 in vitro. Antiviral Res. 2020; https://doi.org/10.1016/j.antiviral.2020.104787.

27. Cortegiani A, Ingoglia G, Ippolito M, Giarratano A, Einav S. A systematic review on the efficacy and safety of chloroquine for the treatment of COVID-19. Crit. Care. 2020; pii: S0883-9441[20]30390-7. doi: 10.1016/j.jcrc.2020.03.005.

28. Takeda K, Kaisho T, Akira S. Toll-Like Receptors. Annu Rev Immunol 2003; 21: 335-76.

29. Chen Z, Hu J, Zhang Z, Jiang S, Han S, Yan D, et al. Efficacy of hydroxychloroquine in patients with COVID-19: results of a randomized clinical trial. 2020; doi:https://doi.org/10.1101/2020.03.22.20040758.

30. Molina JM, Delaugerre C, Goff JL, Mela-Lima B, Ponscarme D, Goldwirt L, et al. No Evidence of Rapid Antiviral Clearance or Clinical Benefit with the Combination of Hydroxychloroquine and Azithromycin in Patients with Severe COVID-19 Infection. Med Mal Infect. 2020; pii: S0399-077X[20]30085-8. doi: 10.1016/j.medmal.2020.03.006.

31. https://www.accessdata.fda.gov/scripts/cder/daf/. Accessed 26 April 2020. 
32. Elyazar I; Hay B. Malaria Distribution, Prevalence, Drug Resistance, and control in Indonesia. Adv Parasit. 2011; 74: 41-175.

33. Gurwitz D. Angiotensin receptor blockers as tentative SARS-CoV-2 therapeutics. Drug Dev Res. 2020; doi: 10.1002/ddr.21656.

34. Furuhashi M, Moniwa N, Mita T, Fuseya T, Ishimura S, Ohno K, et al. Urinary Angiotensin-Converting Enzyme 2 in Hypertensive Patients May Be Increased by Olmesartan, an Angiotensin II Receptor Blocker. Am J Hypertens. 2014; 28: 15-21.

35. Diaz JH. Hypothesis: angiotensin-converting enzyme inhibitors and angiotensin receptor blockers may increase the risk of severe COVID-19. J Travel Med. 2020;doi: 10.1093/jtm/taaa041.

36. Imai Y, Kuba K, Rao S, Huan Y, Guo F, Guan B, et al. Angiotensin-converting enzyme 2 protects from severe acute lung failure. Nature. 2005; 436:112-6.

37. Nicholls J, Peiris M. Good ACE, bad ACE do battle in lung injury, SARS. Nat Med. 2005; 11: 821-2.

38. Fang L, Karakiulakis $G$, Roth M. Are patients with hypertension and diabetes mellitus at increased risk for COVID-19 infection? Lancet Respir Med. 2020; 8:e21. doi: 1016/S2213-2600[20]30116-8.

39. Yamamoto M, Matsuyama S, Li X, Takeda M, Kawaguchi Y, Inoue J, et al. Identification of Nafamostat as a Potent Inhibitor of Middle East Respiratory Syndrome Coronavirus S ProteinMediated Membrane Fusion Using the Split-Protein-Based Cell-Cell Fusion Assay. Antimicrob. Agents Chemother. 2016; 60: 6532-9.

40. Geetha R, Lakshmi D, Roy A. A review on nature's immune boosters. Int J Pharm Sci Rev Res. 2012; 13: 43-52.

41. Kubala J. The 15 Best Supplements to Boost Your Immune System Right Now. https://www.healthline.com/nutrition/immune-boosting-supplements. Accessed 30 April

42. Daneshkhah A, Eshein A, Subramanian H, Roy HK, Backman V. The Role of Vitamin D in Suppressing Cytokine Storm in COVID-19 Patients and Associated Mortality. medRxiv 2020; doi:https://doi.org/10.1101/2020.04.08.20058578.

43. Fookes C. Can vitamin C prevent or treat COVID-19 [coronavirus]? https://www.drugs.com/medicalanswers/vitamin-protect-you-covid-19-coronavirus-disease-3534829/. Accessed 7 May 2020.

44. https://pubchem.ncbi.nlm.nih.gov/compound. Accessed 27 April 2020.

45. drugs.com. Accessed 4 May 2020.

\section{Tables}

\section{Table 1: Selected drugs for combinatorial therapy.}




\begin{tabular}{|c|c|c|c|c|}
\hline Drug Name & $\begin{array}{l}\text { Viral } \\
\text { protein }\end{array}$ & Function of the drug & $\begin{array}{l}\text { Binding } \\
\text { energy } \\
\text { (kcal/mol) }\end{array}$ & Remarks \\
\hline Fla vipiravir & nsp14 & $\begin{array}{l}\text { selectively inhibits RNA polymerase and prevents replication of the viral } \\
\text { genome }\end{array}$ & -5.8 & $\begin{array}{l}\text { Not } \\
\text { chosen }\end{array}$ \\
\hline \multirow[t]{8}{*}{ Remdesivir } & nsp14 & \multirow{8}{*}{$\begin{array}{l}\text { nucleoside analog that is expected to inhibit the action of RNA polymerase } \\
\text { by incorporating those into RNA during replication and/or transcription }\end{array}$} & -6.9 & \multirow[t]{8}{*}{ Chosen } \\
\hline & nsp15 & & -9.5 & \\
\hline & nsp10 & & -7.2 & \\
\hline & $\mathrm{RdRp}$ & & -7.4 & \\
\hline & $\mathrm{NC}$ & & -8.0 & \\
\hline & Helicase & & -8.2 & \\
\hline & $\begin{array}{l}\text { E } \\
\text { protein }\end{array}$ & & -7.7 & \\
\hline & $\begin{array}{l}\text { Spike- } \\
\text { RBD }\end{array}$ & & -7.1 & \\
\hline Ribavirin & nsp14 & $\begin{array}{l}\text { Ribavirin triphosphate (RTP) is the predominant metabolite which directly } \\
\text { inhibits viral mRNA polymerase by binding to the nucleotide binding site of } \\
\text { the enzyme }\end{array}$ & -6.9 & $\begin{array}{l}\text { Not } \\
\text { chosen }\end{array}$ \\
\hline \multirow[t]{3}{*}{ Galidesivir } & nsp14 & \multirow{3}{*}{$\begin{array}{l}\text { binds to viral RNA polymerase at the binding site of natural nucleotides; } \\
\text { thereby leads to structural change in the viral enzyme and disruption of the } \\
\text { viral RNA polymerase activity resulting in premature termination of the } \\
\text { elongating RNA strand }\end{array}$} & -7.6 & \multirow[t]{3}{*}{ Chosen } \\
\hline & nsp15 & & -6.9 & \\
\hline & NC & & -7.0 & \\
\hline \multirow[t]{3}{*}{ Umifenovir } & NC & \multirow[t]{3}{*}{ interacts at the plasma membrane to stabilize it and to prevent viral entry } & -7.0 & \multirow{3}{*}{$\begin{array}{l}\text { Not } \\
\text { chosen }\end{array}$} \\
\hline & Helicase & & -7.0 & \\
\hline & $\begin{array}{l}\text { E } \\
\text { protein }\end{array}$ & & -7.1 & \\
\hline \multirow[t]{5}{*}{ Pirodavir } & nsp15 & \multirow[t]{5}{*}{ binds and stabilizes the viral capsid } & -7.4 & \multirow[t]{5}{*}{ Chosen } \\
\hline & $\mathrm{NC}$ & & -7.9 & \\
\hline & Helicase & & -7.3 & \\
\hline & $\begin{array}{l}\text { E } \\
\text { protein }\end{array}$ & & -6.8 & \\
\hline & $\begin{array}{l}\text { Spike- } \\
\text { RBD }\end{array}$ & & -6.5 & \\
\hline Chloroquine & nsp14 & $\begin{array}{l}\text { increases endosomal and lysosomal pH, thus it might prevent the release } \\
\text { of viral genome, may inhibit RdRp }\end{array}$ & -7.3 & $\begin{array}{l}\text { Not } \\
\text { chosen }\end{array}$ \\
\hline \multirow[t]{7}{*}{ Proguanil } & $\begin{array}{l}\text { E } \\
\text { protein }\end{array}$ & \multirow[t]{7}{*}{ specifically inhibits parasitic dihydrofolate reductase } & -9.5 & \multirow[t]{7}{*}{$\begin{array}{l}\text { May be } \\
\text { chosen }\end{array}$} \\
\hline & Helicase & & -7.7 & \\
\hline & nsp10 & & -7.7 & \\
\hline & nsp14 & & -8 & \\
\hline & nsp15 & & -8.6 & \\
\hline & $\begin{array}{l}\text { Spike } \\
\text { RBD }\end{array}$ & & -7.5 & \\
\hline & $\mathrm{NC}$ & & -9.5 & \\
\hline \multirow[t]{4}{*}{ Quinine } & $\begin{array}{l}\text { E } \\
\text { protein }\end{array}$ & \multirow[t]{4}{*}{ might act similarly like Chloroquine } & -7 & \multirow[t]{4}{*}{$\begin{array}{l}\text { Not } \\
\text { chosen }\end{array}$} \\
\hline & Helicase & & -7.2 & \\
\hline & nsp10 & & -7 & \\
\hline & nsp14 & & -8 & \\
\hline
\end{tabular}




\begin{tabular}{|c|c|c|c|c|}
\hline & \multirow{2}{*}{\begin{tabular}{|l|} 
nsp15 \\
NC
\end{tabular}} & & \multirow{2}{*}{$\begin{array}{r}-7.2 \\
-7.8\end{array}$} & \\
\hline & & & & \\
\hline \multirow[t]{6}{*}{ Mefloquine } & $\begin{array}{l}\text { E } \\
\text { protein }\end{array}$ & \multirow[t]{6}{*}{ not known properly } & -7.7 & \multirow[t]{6}{*}{$\begin{array}{l}\text { May be } \\
\text { chosen }\end{array}$} \\
\hline & Helicase & & -7.8 & \\
\hline & nsp10 & & -7.9 & \\
\hline & nsp14 & & -8.4 & \\
\hline & nsp15 & & -7.6 & \\
\hline & $\mathrm{NC}$ & & -8.9 & \\
\hline Primaquine & nsp14 & may damage cells by oxidative stress & -7.4 & $\begin{array}{l}\text { Not } \\
\text { chosen }\end{array}$ \\
\hline \multirow[t]{6}{*}{ Artesunate } & $\begin{array}{l}\text { E } \\
\text { protein }\end{array}$ & \multirow[t]{6}{*}{$\begin{array}{l}\text { increases reactive oxygen species (ROS) and decreases glutathione on } \\
\text { parasite }\end{array}$} & -7.2 & \multirow[t]{6}{*}{$\begin{array}{l}\text { May be } \\
\text { chosen }\end{array}$} \\
\hline & Helicase & & -7.1 & \\
\hline & nsp10 & & -7.6 & \\
\hline & nsp14 & & -8.4 & \\
\hline & nsp15 & & -8.2 & \\
\hline & $\mathrm{NC}$ & & -8.8 & \\
\hline \multirow[t]{5}{*}{ Amodiaquine } & $\begin{array}{l}\text { E } \\
\text { protein }\end{array}$ & \multirow[t]{5}{*}{ not known properly; might be similar to chloroquine } & -7.2 & \multirow[t]{5}{*}{$\begin{array}{l}\text { Not } \\
\text { chosen }\end{array}$} \\
\hline & nsp10 & & -7.1 & \\
\hline & nsp14 & & -7.5 & \\
\hline & nsp15 & & -7 & \\
\hline & $\mathrm{NC}$ & & -7.6 & \\
\hline \multirow[t]{4}{*}{ Artementher } & Helicase & \multirow{4}{*}{$\begin{array}{l}\text { possibly creates oxidative and metabolic stress, and accumulates } \\
\text { intracellularcalcium }\end{array}$} & -7.5 & \multirow{4}{*}{$\begin{array}{l}\text { Not } \\
\text { chosen }\end{array}$} \\
\hline & nsp10 & & -7 & \\
\hline & nsp15 & & -7.4 & \\
\hline & $\mathrm{NC}$ & & -8 & \\
\hline
\end{tabular}

Table 2: Proposed plans for combinatorial treatments.

\begin{tabular}{|c|c|c|c|c|c|}
\hline Plan & Other drugs & Inhibitors & $\begin{array}{l}\text { Supportive } \\
\text { materials }\end{array}$ & Interferons & Possible side effects \\
\hline A & $\begin{array}{l}\text { Mefloquine (Oral) } \\
\text { and } \\
\text { Remdesivir (IV) / } \\
\text { Galidesivir (IV) }\end{array}$ & $\begin{array}{l}\text { Any ACE / AT1R / } \\
\text { TMPRSS2 } \\
\text { inhibitor }\end{array}$ & $\begin{array}{l}\text { All listed } \\
\text { vitamins }\end{array}$ & Yes & $\begin{array}{l}\text { Dizziness, nausea, vomiting, abdominal } \\
\text { pain, psychiatric effect }\end{array}$ \\
\hline B & $\begin{array}{l}\text { Artesunate (IV) } \\
\text { and Remdesivir (IV) } \\
\text { / Galidesivir (IV) }\end{array}$ & $\begin{array}{l}\text { Any inhibitor } \\
\text { except Losartan }\end{array}$ & $\begin{array}{l}\text { All vitamins } \\
\text { and more } \\
\text { vitamin } \mathrm{D}_{3} \\
\end{array}$ & Yes & $\begin{array}{l}\text { Dizziness, } \\
\text { diarrhoea }\end{array}$ \\
\hline $\mathrm{C}$ & $\begin{array}{l}\text { Proguanil (Oral) } \\
\text { and } \\
\text { Galidesivir (IV) }\end{array}$ & $\begin{array}{l}\text { Any inhibitor } \\
\text { except Losartan }\end{array}$ & All vitamins & Yes & $\begin{array}{l}\text { Nausea, vomiting, abdominal pain, } \\
\text { diarrhea, weakness, loss of appetite, and } \\
\text { dizziness, headache }\end{array}$ \\
\hline $\mathrm{D}$ & $\begin{array}{l}\text { Artesunate (IV) and } \\
\text { Pirodavir (routes yet } \\
\text { to conclude) } \\
\text { (use of Ivermectin } \\
\text { with this is to be } \\
\text { tested) }\end{array}$ & $\begin{array}{l}\text { Any inhibitor } \\
\text { except Losartan }\end{array}$ & $\begin{array}{l}\text { All vitamins } \\
\text { and more } \\
\text { vitamin } \mathrm{D}_{3}\end{array}$ & Yes & Dizziness, diarrhoea, nasal irritation \\
\hline
\end{tabular}


Figures

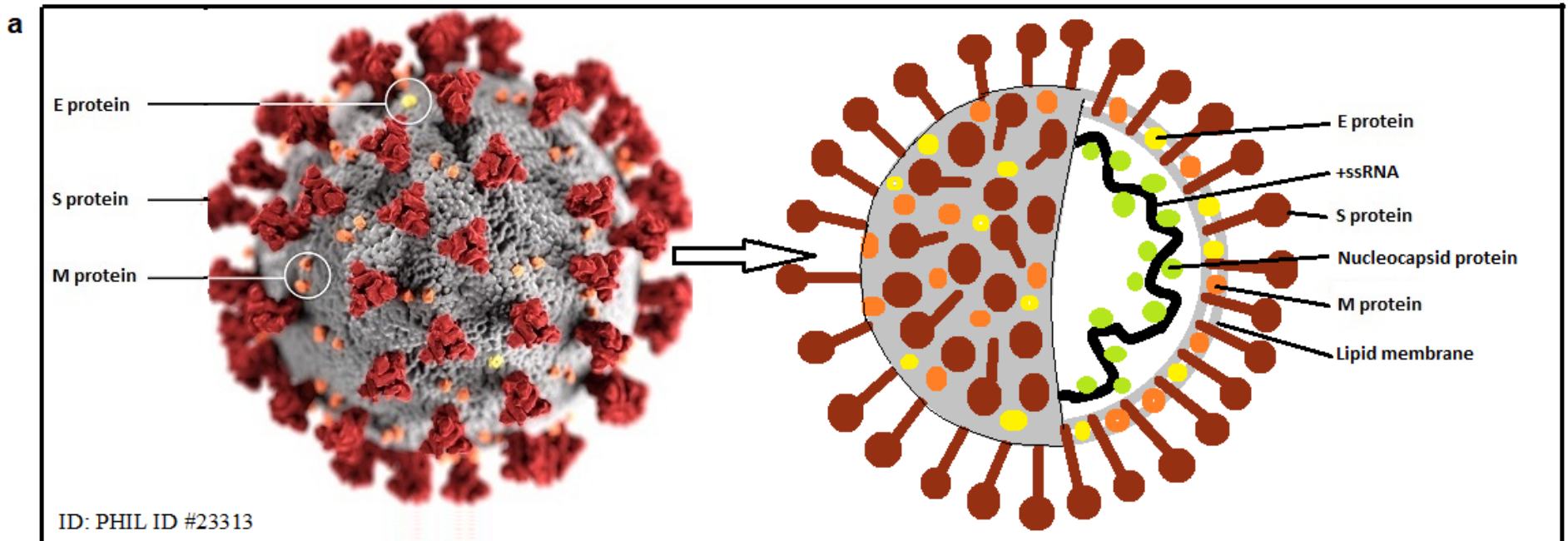

b
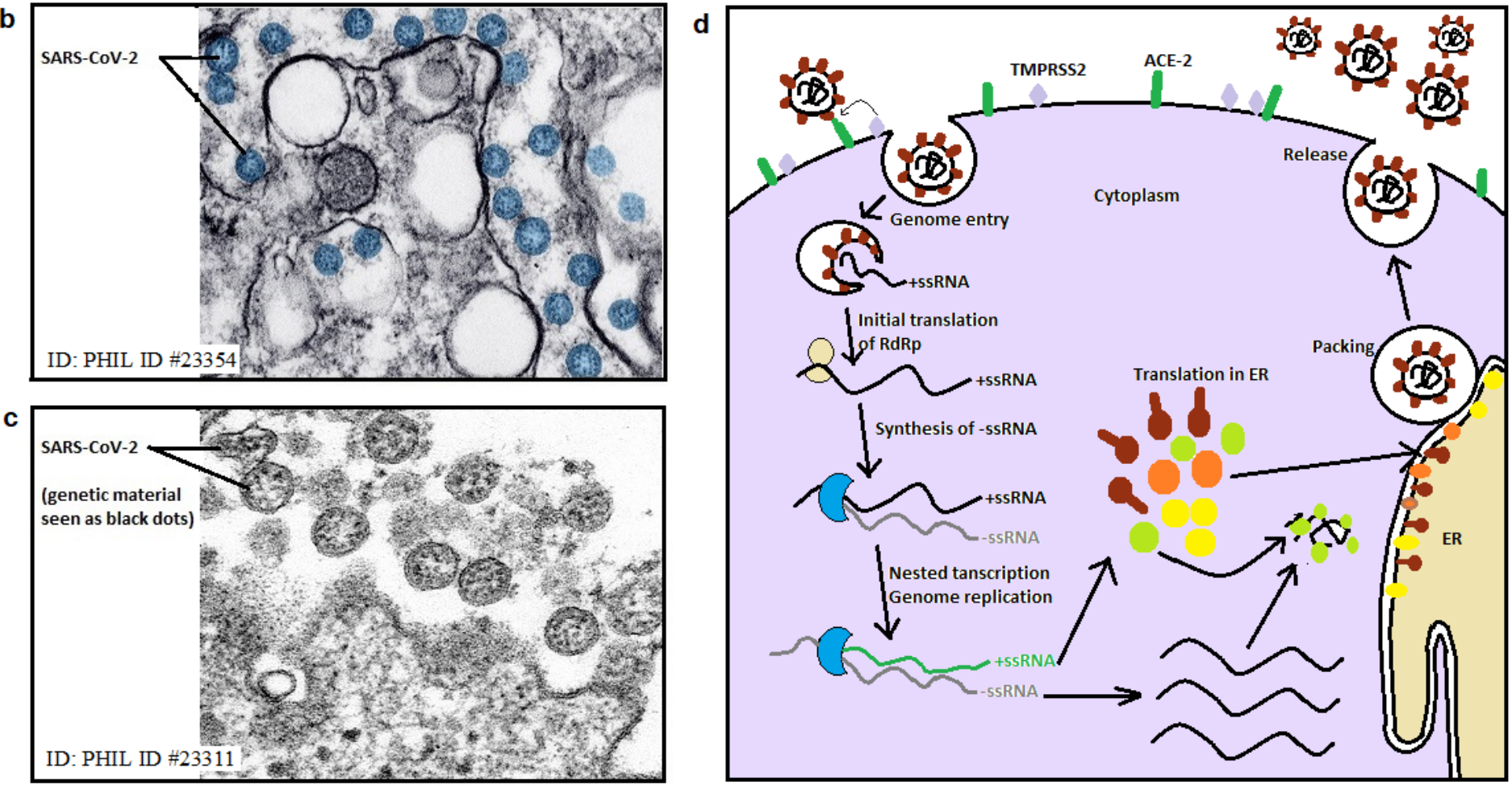

Photographs adopted from (A, B, C) https://www.cdc.gov/media/subtopic/images.htm Images are shown for reference, not presented in proper scale

Fig. 1

\section{Figure 1}

SARS-CoV-2 and its mode of infection. (a) Left part shows the model of SARS-CoV-2 as produced by Swiss Model Repository. The right part indicated by an arrow is a schematic diagram of the virus and its internal parts. (b) and (c) Cross sections of the virus seen under the transmission electron microscopy (TEM) showing its genetic material as black dots. (d) The schematic representation of the steps of establishment of infection inside a host cell. Abbreviations: E protein - Envelope protein; M protein Membrane protein; S protein - Spike glycoprotein; +ssRNA - Positive sense single stranded RNA; ER - 
Endoplasmic reticulum; ACE 2 - Angiotensin converting enzyme 2; TMPRSS2 - transmembrane protease, serine 2 .
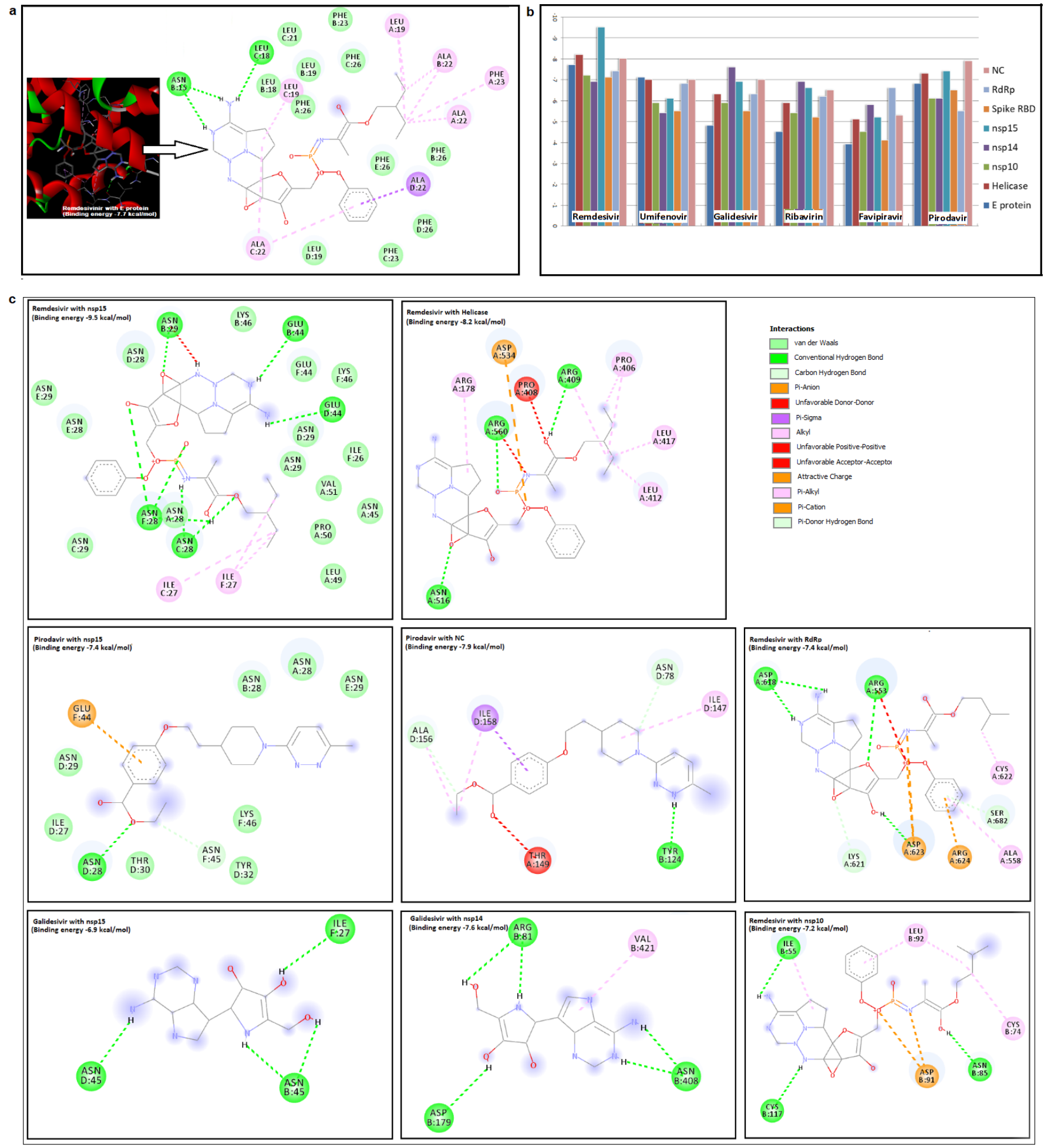

Fig. 2

Figure 2

Docking and interactions of viral proteins and antiviral drugs. (a) Interactions of E protein with Remdesivir are shown in 3- and 2-dimensional representations. (b) The binding energies of the antiviral drugs with the viral proteins are plotted. It should be noted that Remdesivir shows higher binding energies for most 
of the viral proteins compared to other drugs. (c) Interactions are shown for a few viral proteins and antiviral drugs. Docking is analysed in Discovery Studio Visualizer. The 2-dimensional representations of the interacting residues are shown and the binding energies, as calculated in AutoDock Vina, are also indicated. Only a few are shown for simplicity. Types of interactions noted are shown on the right.

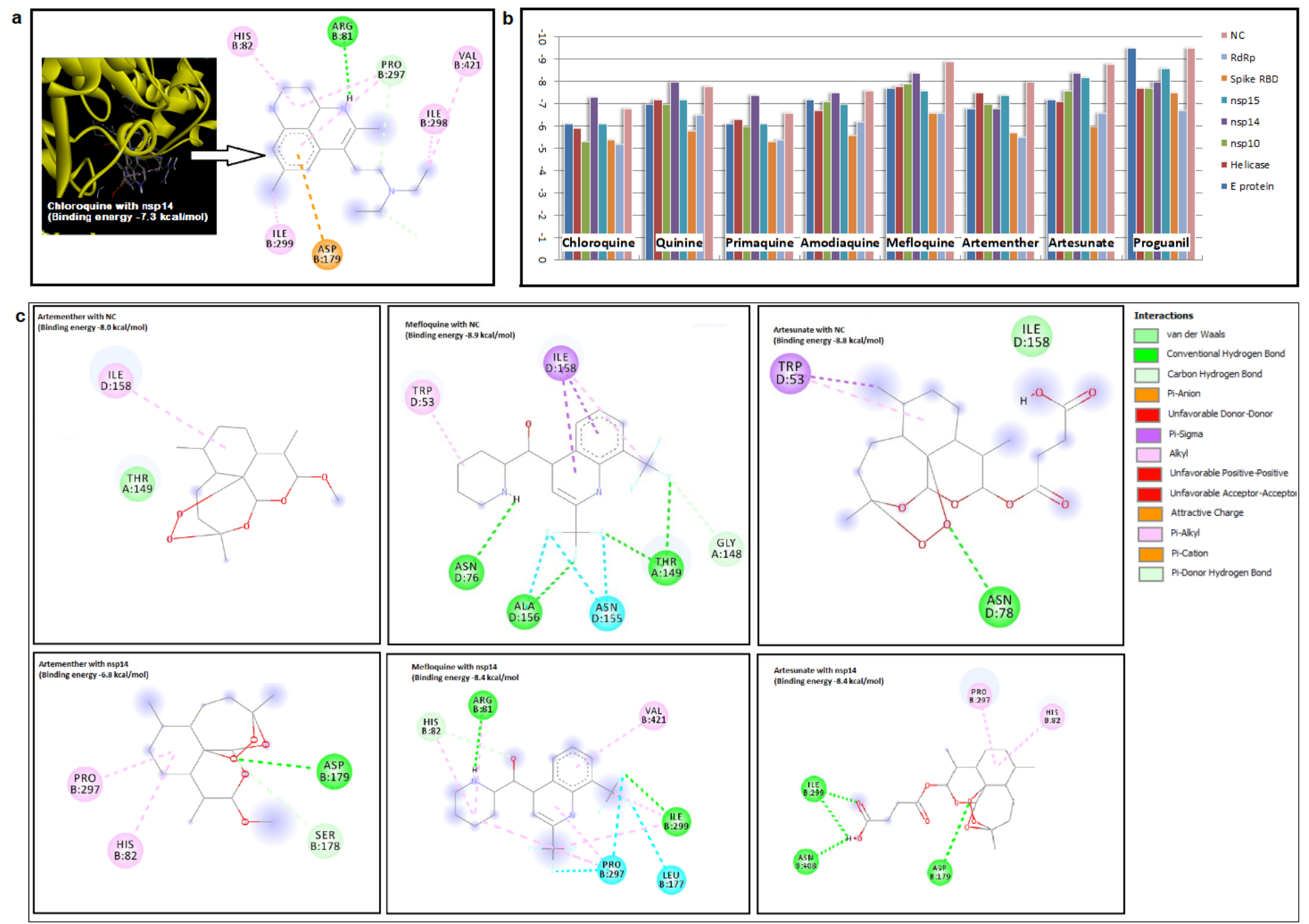

Fig. 3

Figure 3

Docking and interactions of viral proteins and antiparasitic drugs. (a) Interactions of nsp14 with Chloroquine is shown in 3- and 2-dimensional representations. (b) The binding energies of the antiparasitic drugs with the viral proteins are plotted. It should be noted that Chloroquine shows higher binding energies for most of the viral proteins compared to other drugs. (c) Interactions are shown for a few viral proteins and antimalarial drugs. The binding energies for each are indicated also. Only a few are shown for simplicity. Types of interactions noted are shown on the right. 


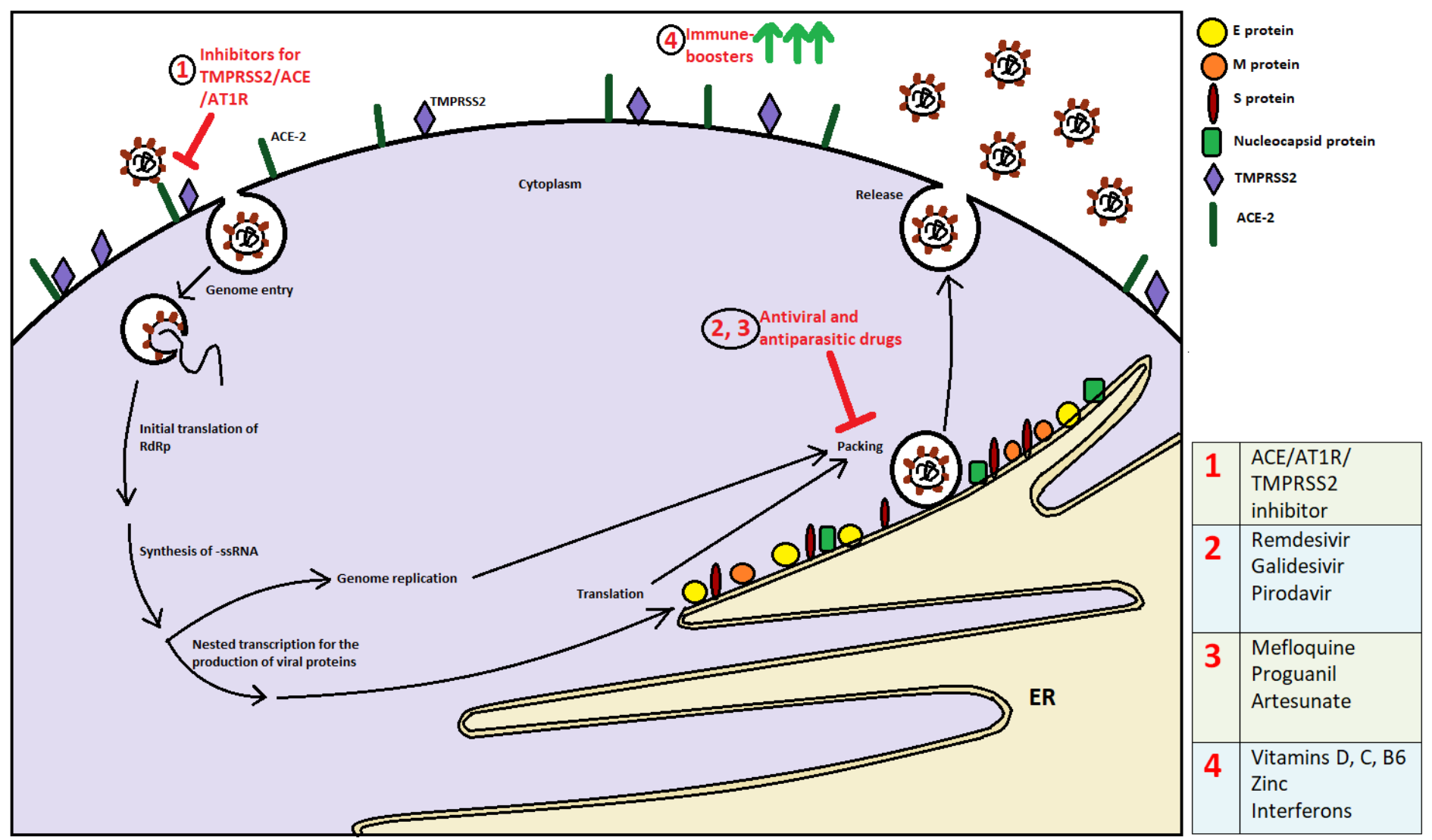

FIGURE 4

\section{Figure 4}

Proposed treatment plans for fighting COVID-19. A set of possible combinatorial treatment plans including an antiviral, an anitiparasitic drug, an inhibitor for preventing host-cell entry, and some immuneboosters may be used to treat COVID-19 completely. In the very initial step of infection, inhibitor[s] may be used to prevent host-cell entry of the virus. In the next step, some viral proteins may be blocked by antiviral and antiparasitic drugs so that efficient packing of the virus can be prevented. Finally, a set of supplements and interferon(s) may be administered to support the immune system of the patient for complete recovery.

\section{Supplementary Files}

This is a list of supplementary files associated with this preprint. Click to download.

- FigureS1.jpg

- Figures2.jpg

- TableS1.png

- Tables2.png

- Tables3.png 
- Tables4.png

Page 17/17 